\title{
The effect of supplementing diets with dried fennel and thyme on the zootechnical parameters and caecal microflora of growing rabbit
}

\author{
M. Benlemlih, A. Aarab, M. Bakkali, A. Arakrak and A. Laglaoui ${ }^{1}$ \\ Abdelmalek Essaâdi University, Faculty of Science and Technology \\ 416 Tangier, Morocco
}

KEY WORDS: rabbit, fennel, thyme, growth parameters, caecal microflora

Received: 2 December 2013

Revised: 13 November 2014

Accepted: 28 November 2014

${ }^{1}$ Corresponding author:

e-mail: laglaouiamin@yahoo.fr

\begin{abstract}
The objective of this study was to evaluate the effect of fennel and thyme dietary supplements on the feeding of rabbits. Eighty-five weaned rabbits ( 35 days old), white New Zealand (of both sexes), were divided into four groups and submitted to the following dietary treatments: Control diet, diet $\mathrm{F}$ (Control diet $+2.5 \%$ Foeniculum vulgare seeds), diet $\mathrm{T}$ (Control diet $+2.5 \%$ Thymus capitatus leaves) and diet FT (Control diet + 2.5\% Foeniculum vulgare seeds and Thymus capitatus leaves) for twenty-five days. The treatment with fennel and thyme had a beneficial effect on the mortality rate $(18 \%)$. However the growth rate, feed conversion ratio and carcass yield were not influenced by dietary fennel and/or thyme supplementation. The antimicrobial effect of thyme $(2.5 \%)$ was observed only against $C$. perfringens in the caecum $(P<0.05)$, but no effect was observed on the caecal count of or $C$. perfringens in the other treated groups.
\end{abstract}

\section{Introduction}

Weaning is the most critical period in rabbit breeding; it is associated with a higher risk of digestive disorders in growing rabbits (Krieg et al., 2009). Antibiotics as growth promoters (AGPs) have been widely used in specific diets to prevent these digestive disorders. Recently, the concerns about possible antibiotic residues and disease resistance have aroused great caution in their use in the animal industry (Jang et al., 2007). In January 2006, the European Commission banned the marketing and use of antibiotics as growth promoters in feed (Huyghebaert et al., 2011). The decreased use of AGPs in animal diets necessitates finding alternative feed additives. Aromatic plants are being explored as options to antimicrobials, due to their different active substances. The influence of some medicinal plants and their extracts on rabbit has been studied (Eiben et al., 2004; El-Nattat and El-Kady, 2007; Soultos et al., 2009; Simonová et al., 2010; Gerencsér et al., 2012). Krieg et al. (2009) found that a herbal feed additive had a positive influence on performance and health in weaned rabbits.

Fennel (Foeniculum vulgare) and its preparations are used to cure various disorders, and also act as a carminative, digestive and diuretic agent. Anethole and its isomers present in fennel oil are responsible for its antimicrobial effects (Gulfraz et al., 2008). Several studies have been published on the biological properties of Thymus capitatus as an antibacterial, antifungal and antioxidant agent (El Ouariachi et al., 2011). 
The aim of this study was to examine the effects of Foeniculum vulgare and Thymus capitatus as natural feed supplements on growth performance and caecal microflora in weaned rabbits.

\section{Material and methods}

\section{Animals and experimental procedure}

A total of 85 weaned rabbits white New Zealand (35 days old; male and female; $800 \pm 100 \mathrm{~g}$ initial body weight), were divided into four groups and submitted to the following dietary treatments (Table 1) for twenty-five days: Control diet; diet T $(2.5 \%$ Thymus capitatus leaf powder mixed with the Control diet); diet F (2.5\% Foeniculum vulgare fruit powder mixed with the Control diet) and diet FT (2.5\% Thymus capitatus and Foeniculum vulgare powder mixed with the Control diet).

The rabbits were kept in standard cages (7 animals per cage, except the last FT cage with 8 animals) in a building with temperatures between 15 and $20^{\circ} \mathrm{C}$, and humidity levels between $60 \%$ and $70 \%$. The duration of daily illumination was $16 \mathrm{~h}$. The rabbits had access to feed and water ad libitum. The body weight of rabbits, feed consumption and mortality rates were measured every week during the experiment.

\section{Chemical analysis}

Chemical analysis of diets was performed following the methods of AOAC (1991) for dry matter, ash and crude protein, and of Van Soest et al. (1991) for acid detergent fibre (ADF), neutral detergent fibre (NDF) and detergent lignin (ADL).

Table 1. Ingredients and chemical composition and nutritive value of diets

\begin{tabular}{|c|c|c|c|}
\hline Ingredients & $\%$ & Chemical composition, $\mathrm{g}$ & $100 g^{-1}$ \\
\hline Wheat bran & 28.5 & Dry matter & 92.2 \\
\hline Maize & 9.5 & Ash & 8.71 \\
\hline Soyabean meal & 9.5 & Crude protein & 21.1 \\
\hline Sunflower meal & 14.2 & Ether extract & 5.28 \\
\hline Lucerne, hopped & 33.75 & NDF & 39.4 \\
\hline Vegetable oil & 2.8 & $A D F$ & 20.0 \\
\hline Salt & 0.5 & $A D L$ & 4.52 \\
\hline Premix $^{1}$ & 0.6 & Digestible energy, & 2522 \\
\hline DL-Methionine & 0.1 & $\mathrm{k}^{2} \mathrm{l} \mathrm{kg}^{-1}$ & \\
\hline L-Lysine & 0.2 & & \\
\hline Dicalcium phosphate & 0.25 & & \\
\hline Calcium carbonate & 0.1 & & \\
\hline \multicolumn{4}{|c|}{$\begin{array}{l}11 \mathrm{~kg} \text { of Premix provides: IU: vit. A } 1000000 \text {, vit. D } 300000 \text {; g: vit. E } \\
2 \text {, vit. K } 0.4 \text {, vit. } B_{1} 0.075 \text {, vit } B_{2} 0.4 \text {, vit. } B_{3} 1.218 \text {, vit. } B_{5} 0.099 \text {, vit } B_{6} \\
0.083 \text {, vit. } B_{9} 0.190 \text {, vit. } B_{12} 0.030 \text {, biotin } 0.005 \text {, cuivre } 0.2, F e 4, Z n \\
\text { I } 0.012 \text {, Se } 0.012 \text {, Co } 0.020, M n 6 \text {, choline chloride and } Q S P \text { calcium } \\
57 \text {; Premix contained } 50 \text { ppm of salinomycin }\end{array}$} \\
\hline
\end{tabular}

\section{Bacteriological analysis}

Three animals from each group were slaughtered on days 35,45 and 60 . Bacteria from caecal samples were isolated by the standard microbiological method using the appropriate dilutions in Ringer solution. Dilutions were plated onto the following media: Mac Conkey agar for E. coli, incubated at $37^{\circ} \mathrm{C}$ for $24 \mathrm{~h}$ and Tryptose Sulphite agar with the antibiotic, D-Cycloserine (TSC) for C. perfringens, incubated for $48 \mathrm{~h}$ at $37^{\circ} \mathrm{C}$, with the counts determined according to the ISO 7937 standard (1997). The bacterial counts were expressed in colony forming units per gram $\left(\log 10 \mathrm{CFU} \cdot \mathrm{g}^{-1}\right)$.

\section{Statistical analysis}

The results are given as mean \pm standard deviation (SD), statistical evaluation of the results was performed by one-way ANOVA with the level of significance set at $P<0.05$ and the Chi Square test for mortality.

\section{Results}

The liveweight, growth rate, feed intake, feed conversion rate, carcass yield and mortality of rabbits during the experiment are presented in Table 2.

The group of rabbits fed with fennel- and/or thyme-supplemented diet appeared to eat large quantities of feed and presented a higher body weight and growth rate when compared with the control group during the first week of treatment. These parameters were not influenced by dietary fennel or thyme supplementation after this period.

Although the feed conversion rate did not differ significantly $(P<0.05)$ when the experimental period was considered as a whole, the rate of conversion for groups $\mathrm{F}$ and $\mathrm{T}$ tended to be better during the third week of treatment. The mean carcass yield also did not differ significantly among the groups, but the liver yield varied significantly only after ten days of treatment. The highest mortality rate was observed in the control group, followed by the $\mathrm{F}$ and then the T group, with the FT group presenting the lowest mortality.

Effects of dietary fennel and/or thyme on caecal microbial counts are presented in Table 3. The CFU of in digesta taken from the caecum were not influenced by dietary supplementation of medicinal plants. However, rabbits fed diets containing thyme $(2.5 \%)$ showed a significant $(P<0.05)$ reduction in CFU of $C$. perfringens after three weeks of treatment (on day 60) when compared with the others. 
Table 2. Effect of dietary supplementation with fennel seeds and thyme leaves on rabbit growth performance and mortality

\begin{tabular}{|c|c|c|c|c|c|c|}
\hline \multirow{2}{*}{ Indices } & \multirow{2}{*}{ Days } & \multicolumn{5}{|l|}{ Group } \\
\hline & & $\mathrm{C}$ & $\mathrm{F}$ & $\mathrm{T}$ & FT & $P$ \\
\hline \multirow[t]{4}{*}{ Body weight (BW), g; mean \pm SD } & 35 & $782 \pm 80$ & $811 \pm 94$ & $802 \pm 88$ & $796 \pm 80$ & 0.74 \\
\hline & 42 & $977 \pm 111$ & $1048 \pm 120$ & $1093 \pm 130$ & $1070 \pm 120$ & 0.047 \\
\hline & 49 & $1143 \pm 158$ & $1195 \pm 180$ & $1253 \pm 180$ & $1278 \pm 173$ & 0.227 \\
\hline & 56 & $1363 \pm 250$ & $1358 \pm 200$ & $1488 \pm 135$ & $1386 \pm 174$ & 0.434 \\
\hline \multirow[t]{4}{*}{ Feed intake, $g \cdot d^{-1} ;$ mean \pm SD } & 35 & $53.7 \pm 10$ & $59.7 \pm 12$ & $66.0 \pm 10$ & $61.0 \pm 8$ & 0.093 \\
\hline & 42 & $63.0 \pm 13$ & $77.7 \pm 7$ & $88.3 \pm 10$ & $106.7 \pm 11$ & 0.006 \\
\hline & 49 & $97.0 \pm 15$ & $101.3 \pm 9$ & $100.3 \pm 10$ & $110.6 \pm 11$ & 0.591 \\
\hline & 56 & $136.5 \pm 19$ & $108.3 \pm 20$ & $113.7 \pm 17$ & $116.6 \pm 22$ & 0.395 \\
\hline \multirow[t]{3}{*}{ Growth rate, $g \cdot d^{-1} ;$ mean $\pm S D$} & $35-42$ & $28.4 \pm 13$ & $33.9 \pm 10$ & $38.7 \pm 15$ & $39.0 \pm 11$ & 0.03 \\
\hline & $42-49$ & $26.6 \pm 9$ & $32.0 \pm 13$ & $31.5 \pm 18$ & $31.9 \pm 13$ & 0.713 \\
\hline & $49-56$ & $32.9 \pm 14$ & $21.9 \pm 9$ & $24.6 \pm 20$ & $16.0 \pm 8$ & 0.388 \\
\hline \multirow[t]{3}{*}{ Feed conversion ratio; mean $\pm \mathrm{SD}$} & $35-42$ & $2.24 \pm 0.7$ & $2.25 \pm 0.6$ & $2.08 \pm 0.8$ & $2.25 \pm 0.7$ & 0.91 \\
\hline & $42-49$ & $2.99 \pm 0.7$ & $3.51 \pm 0.9$ & $2.80 \pm 0.8$ & $3.33 \pm 0.9$ & 0.947 \\
\hline & $49-56$ & $4.18 \pm 0.9$ & $3.42 \pm 0.6$ & $3.05 \pm 0.8$ & $5.90 \pm 0.4$ & 0.006 \\
\hline \multirow[t]{2}{*}{ Carcass yield, $(\%$ of $\mathrm{BW})$ mean $\pm \mathrm{SD}$} & 45 & $51 \pm 4$ & $48 \pm 2$ & $47 \pm 6$ & $49 \pm 1$ & 0.773 \\
\hline & 60 & $47 \pm 9$ & $52 \pm 1$ & $53 \pm 2$ & $58 \pm 10$ & 0.425 \\
\hline \multirow[t]{2}{*}{ Liver yield, ( $\%$ of BW); mean \pm SD } & 45 & $3.0 \pm 0.5$ & $4.3 \pm 0.4$ & $3.7 \pm 0.4$ & $5.1 \pm 0.7$ & 0.01 \\
\hline & $60^{\mathrm{d}}$ & $4.0 \pm 0.7$ & $4.6 \pm 0.4$ & $4.1 \pm 1$ & $5.3 \pm 0.7$ & 0.406 \\
\hline \multirow[t]{4}{*}{ Mortality ${ }^{1}, \% ;$ mean \pm SD } & $35-42$ & 4.8 & 0 & 0 & 0 & \\
\hline & $42-49$ & 14.3 & 4.8 & 19.0 & 0 & \\
\hline & $49-56$ & 52.4 & 33.3 & 9.5 & 18.1 & \\
\hline & $35-60$ & 71.4 & 38.1 & 28.6 & 18.1 & $<0.05$ \\
\hline
\end{tabular}

${ }^{1}$ mortality are analysed using a $\times 2$ test at $P<0.05$

Table 3. Counts of $E$. coli and C. perfringens in caecum of rabbits $\left(\log 10 \mathrm{cfu} \cdot \mathrm{g}^{-1}(\right.$ mean $\pm \mathrm{SD})$

\begin{tabular}{|c|c|c|c|c|c|c|}
\hline \multirow{2}{*}{ Days } & \multirow{2}{*}{ Bacteria } & \multicolumn{5}{|l|}{ Group } \\
\hline & & $\mathrm{C}$ & $\mathrm{F}$ & $\mathrm{T}$ & $\mathrm{FT}$ & $P$ \\
\hline \multirow[t]{2}{*}{35} & E.coli & & $2.98 \pm 0.5$ & & & \\
\hline & C. perfringens & & $2.81 \pm 0.5$ & & & \\
\hline \multirow[t]{2}{*}{45} & E. coli & $4.03 \pm 0.6$ & $3.99 \pm 0.1$ & $3.59 \pm 0.8$ & $3.80 \pm 0.4$ & 0.814 \\
\hline & C. perfringens & $2.92 \pm 0.3$ & $2.79 \pm 0.1$ & $2.82 \pm 0.3$ & $2.75 \pm 0.3$ & 0.895 \\
\hline \multirow[t]{2}{*}{60} & E. coli & $4.56 \pm 0.2$ & $4.41 \pm 0.1$ & $3.94 \pm 0.6$ & $4.09 \pm 0.6$ & 0.606 \\
\hline & C. perfringens & $3.04 \pm 0.1$ & $2.60 \pm 0.2$ & $1.69 \pm 0.1$ & $2.50 \pm 0.4$ & 0.035 \\
\hline
\end{tabular}

\section{Discussion}

In recent years, aromatic plants and their extracts have received increased attention as potential alternatives to antibiotic growth promoters. It is known that their pharmaceutical properties are partially due to the essential oils they contain (Edris, 2007). There is very limited information on the effects of herbs or their compounds on the growth of rabbits. In agreement with our present study, Gerencsér et al. (2012) found that supplementing the diet with 3\% thyme had no effect on rabbit weight gain or feed consumption. Those parameters were also not affected by supplementation with dietary oregano essential oil (Soultos et al., 2009). Sengül et al. (2008) observed no change in weight gain or feed conversion when growing Japanese quails were fed diets supplemented with $2.5 \mathrm{ml} \cdot \mathrm{kg}^{-1}$ thyme oil or $100 \mathrm{ml} \cdot 1^{-1}$ extracted water of thyme (Thymus vulgaris L.). Hernandez et al. (2004) found that the addition of 5,000 ppm Labiatae extract from thyme, sage and rosemary to broilers diets had no beneficial effect on the feed conversion ratio or on feed intake. Bampidis et al. (2005) also observed that supplementation of diets with dried oregano (Origanum vulgare) leaves had no positive influence on performance or carcass characteristics of lambs. However Bölükbaşi and Erhan (2007) showed that feeding laying hens a diet containing $0.1 \%$ and $0.5 \%$ thyme improved feed conversion.

Lee et al. (2003) found that some bioactive components of essential oils, especially carvacrol, improved feed conversion ratios in broiler chickens. They proposed that the effect of carvacrol on feed 
conversion ratios could be related to increased efficiency of feed utilization.

Low mortality was found by Simonová et al. (2008) during the experimental application of ginseng extracts to rabbits. These findings were similar to our experimental results with the combined supplementation with fennel and thyme, which also appears to decrease digestive disorders while significantly $(P<0.05)$ reducing the mortality rate. A diet enriched with some plant extracts is beneficial for the health rabbits (Simonová et al., 2010). In contrast, Erdelyi et al. (2008) found that combined supplements of essential oils of rosemary $(0.15 \%)$ and garlic $(0.025 \%)$ increased mortality. In the study of Eiben et al. (2004), the inclusion of anise and fenugreek seeds at a level of $6 \mathrm{~g} \cdot \mathrm{kg}^{-1}$ diet increased the pre-weaning mortality in New Zealand white rabbits. However, Gerencsér et al. (2012) observed that supplementing the diet with 3\% thyme had no effect on rabbit mortality.

The Foeniculum vulgare fruit extracts and oil are rich in trans-anethole and other compounds and are effective against $C$. albicans, and other similar organisms (Gulfraz et al., 2008). In the current study, the supplementation of $2.5 \%$ thyme and $2.5 \%$ fennel and thyme insignificantly decreased caecal counts of when compared with the control group. So the counts of in the caecum of the rabbits were not affected by any of the supplemental treatments, but the supplementation with $2.5 \%$ thyme significantly lowered caecal $C$. perfringer populations $(P<0.05)$ as compared with the control and the other group. Bölükbaşi and Erhan (2007) showed that $0.1 \%$ and $0.5 \%$ of thyme significantly reduced E. coli concentrations in the faeces of laying hens.

The essential oils from the thymus species are rich sources of phenolic monoterpenes such as thymol and carvacrol (Karousou et al., 2005; Amiri, 2012). Numerous in vitro studies have demonstrated that essential oils, including these molecules, display antimicrobial activity (Celikel and Kavas, 2008; Cosge et al., 2009; Chedia et al., 2013). C. perfringens were found to be sensitive to carvacrol, cinnamaldehyde, citral, limonene, thymol, particularly at a higher concentration $\left(500 \mathrm{mg} \cdot \mathrm{1}^{-1}\right)$, the same was true for oregano oil, rosemary oil and thyme oil (Ouwehand et al., 2010).

\section{Conclusions}

In this study, dietary supplementation with $2.5 \%$ fennel and/or thyme did not affect the growth of rabbits, but significantly reduced their mortality during the fattening period. This reduction could be related to the decrease in bacteria concentrations in the caecum due to the effects of the essential oils contained in these medicinal plants, which must be confirmed by further investigation and research.

\section{Acknowledgements}

The authors would like to thank Mr. Javier García Alonso from the Department of Animal Production, University Polytechnic of Madrid for co-operation in this experiment.

\section{References}

Amiri H., 2012. Essential oils composition and antioxidant properties of three thymus species. Evid. Based Complement Alternat. Med. doi: 10.1155/2012/728065

AOAC, 1991. Association of Official Analytical Chemists, Official Methods of Analysis. $15^{\text {th }}$ Edition. Washington, DC

Bampidis V.A., Christodoulou V., Florou-Paneri P., Christaki E., Spais A.B., Chatzopoulou P.S., 2005. Effect of dietary dried oregano leaves supplementation on performance and carcass characteristics of growing lambs. Anim. Feed Sci. Tech. 121, 285-295

Bölükbaşi Ş.C., Erhan M.K., 2007. Effect of dietary thyme (Thymus vulgaris) on laying hens performance and Escherichia coli (E. coli) concentration in feces. IJNES - Int. J. Natural Engineering Sci.1 (2), 55-58

Celikel N., Kavas G., 2008. Antimicrobial properties of some essential oils against some pathogenic microorganisms. Czech J. Food Sci. 26,174-181

Chedia A., Ghazghazi H., Dallali S., Houssine S., Brahim H., Abderazzak M., 2013. Comparison of chemical composition, antioxidant and antimicrobial activities of Thymus capitatus L. essential oils from two Tunisian localities (Sousse and Bizerte). Int. J. Agron. Plant. Prod. 4, 1772-1781

Cosge B., Turker A., Ipek A., Gurbuz B., Arslan N., 2009. Chemical compositions and antibacterial activities of the essential oils from aerial parts and corollas of origanum acutidens (Hand.Mazz.) letswaart, an endemic species to Turkey. Molecules 14, 1702-1712

Edris A.E., 2007. Pharmaceutical and therapeutic potentials of essential oils and their individual volatile constituents: A review. Phytother. Res. 21, 308-323

Eiben C.S., Rashwan A.A., Kustos K.3, Godor-Surmann K., Szendro Z.S., 2004. Effect of anise and fenugreek supplementation on performance of rabbit does. In: Prodeecings of $8^{\text {th }}$ World Rabbit Congress.Puebla (Mexico), pp. 805-810

El-Nattat W.S., El-Kady R.I., 2007. Effect of different medicinal plant seeds residues on the nutritional and reproductive performance of adult male rabbits. Int. J. Agr. Biol. 9, 479-485

El Ouariachi E.M., Paolini J., Bouyanzer A., Tomi P., Hammouti B., Salghi R., Majidi L., Costa J., 2011. Chemical composition and antioxidant activity of essential oils and solvent extracts of Thymus capitatus (L.) Hoffmanns and link from Morocco. J. Med. Plants Res. 5, 5773-5778

Erdelyi M., Matics Z., Gerencsér Z., Princz Z., Szendrı Z., Mézes M., 2008. Study of the effect of Rosmary (Rosmarinus officinalis) and garlic (Allium sativum) essential oils on the performance of rabbit. In: Proceedings of the $9^{\text {th }}$ World Rabbit Congress. Verona (Italy), pp. 649-654 
Gerencsér Zs., Szendrő Zs., Matics Zs., Radnai I., Kovács M., Nagy I., Dal Bosco A., Dalle Zotte A., 2012. Dietary supplementation of spirulina (Arthrospira platensis) and thyme (Thymus vulgare L.). Part 1: Effect on productive performance of growing rabbits. In: Proceedings of $10^{\text {th }}$ World Rabbit Congress. Sharm El- Sheikh (Egypt), pp. 657-661

Gulfraz M., Mehmood S., Minhas N., Jabeen N., Kausar R., Jabeen K., Arshad G., 2008. Composition and antimicrobial properties of essential oil of Foeniculum vulgare. Afr. J. Biotechnol. 7, 4364-4368

Hernandez F., Madrid J., Garcia V., Orengo J., Megias M.D., 2004. Influence of two plant extracts on broiler performance, digestibility, and digestive organ size. Poultry Sci. 83, 169-174

Huyghebaert G., Ducatelle R., Van Immerseel F., 2011. An update on alternatives to antimicrobial growth promoters for broilers. Vet. J. 187, 182-188

ISO 7937 Standard, 1997. Microbiology of food and animal feeding stuffs. Horizontal method for enumeration of Clostridium perfringens - Colony-count technique

Jang I.S., Ko Y.H., Kang S.Y., Lee C.Y., 2007. Effect of a commercial essential oil on growth performance, digestive enzyme activity and intestinal microflora population in broiler chickens. Anim. Feed Sci. Tech. 134, 304-315

Karousou R., Koureas D.N., Kokkini S., 2005. Essential oil composition is related to the natural habitats: Coridothymus capitatus and Satureja thymbra in NATURA 2000 sites of Crete. Phytochemistry 66, 2668-2673

Krieg R., Vahjen W., Awad W., Sysel M., Kroeger S., Zocher E., Hulan H.W., Arndt G., Zentek J., 2009. Performance, digestive disorders and the intestinal microbiota in weaning rabbits are affected by a herbal feed additive. World Rabbit Sci. 17, 87-95
Lee K.W., Everts H., Kappert H.J., Yeom K.H., Beynen A.C., 2003. Dietary carvacrol lowers body weight gain but improves feed conversion in female broiler chickens. J. Appl. Poultry Res. 12, 394-399

Ouwehand A.C., Tiihonen K., Kettunen H., Peuranen S., Schulze H., Rautonen N., 2010. In vitro effects of essential oils on potential pathogens and beneficial members of the normal microbiota. Vet. Med. Czech. 55, 71-78

Sengül T., Yurtseven S., Cetin M., Kocyigit A., Sögüt B., 2008. Effect of thyme (Thymus vulgaris) extracts on fattening performance, some blood parameters, oxidative stress and dna damage in japanese quails. J. Anim. Feed Sci. 17, 608-620

Simonová M.P., Chrastinová L., Mojto J., Lauková A., Szabóová R., Ján Rafay J., 2010. Quality of rabbit meat and phyto-additives. Czech J. Food Sci. 28,161-167

Simonová M., Szabóová R., Chrastinová L'., Lauková A., Haviarová M., Strompfová V., Plachá I., Faix Š., Vasilková Z., Mojto J., Rafay J., 2008. The use of a ginseng extract in rabbits. In: Proceedings of $9^{\text {th }}$ World Rabbit Congress. Verona (Italy), pp. 809-814

Soultos N., Tzikas Z., Christaki E., Papageorgiou K., Steris V., 2009. The effect of dietary oregano essential oil on microbial growth of rabbit carcasses during refrigerated storage. Meat Sci. 81, 474-478

Van Soest J.P., Robertson J.B., Lewis B.A., 1991. Methods for dietary fiber, neutral detergent fiber and nonstarch polysaccharides in relation to animal nutrition. J. Dairy Sci. 74, 3583-3597 